\title{
Bread for the Departed (Chleb rzucony umartym)
}

\author{
Author: Bogdan Wojdowski
}

First Published: 1971

Translations: German (Brot für die Toten, 1974); Japanese (Shisha-ni nagerareta pan, 1976); Hebrew (Lehem zaruk la-metim, 1981); Esperanto (La pano jetita al la mortintoj, 1990); English (Bread for the Departed, 1997); Hungarian (A holtaknak vetett kenyér, 2014); Italian (Il sentiero, 2015); Spanish (Pan para los muertos, 2017).

About the Author: Bogdan Wojdowski was born into the Jewish family of an upholsterer and carpenter in 1930 in Warsaw. Due to the war and Holocaust he changed his first name from Dawid to Bogdan. Wojdowski belongs to the main group of witnesses of the Holocaust in Poland, having spent three years in the Warsaw Ghetto. He survived as a child (like Henryk Grynberg, Hanna Krall or Wilhelm Dichter) when he was at the age of twelve placed on the Aryan side of Warsaw outside of the ghetto. Wojdowski graduated from the Department of Polish Studies at Warsaw University, worked as a reporter, literary critic, essayist and teacher. He was the co-editor of the Polish weekly Przeglad Kulturalny (1954-1956), co-operated as a reporter for the weekly Wieś (1951-1954), and the Jewish paper Fotks-Sztyme (1971-1974) in Yiddish and Polish. Wojdowski, although generally considered as a part of Generation '56 or Współczesność (named after the cultural magazine of the same name), denied belonging to any literary group or programme. He made his debut with the drama Ramsynit or the Egypt Parable (Ramsynit, czyli przypowieść egipska, 1959), followed by theatre critiques, and short stories (Job's Vacation [Wakacje Hioba], 1962). In his novel Bread for the Departed (Polish book of the year 1971) he processed his traumatic experiences in the ghetto. Having achieved international acclaim, the book was translated into English in 1998 with the euphemistic title Bread for the Departed (literally "Bread Tossed to the Dead") belongs to best known literary works on the Holocaust. Most of Wojdowski's prose is more or less directly devoted to his wartime experiences. After committing suicide on the fifty-first anniversary of the Warsaw Ghetto Uprising on April 19th, 1994 he was buried in the Jewish cemetery in Warsaw.

Further Important Publications: Konotop (1966, Konotop; novel); Maty człowieczek, nieme ptaszę, klatka i świat (1975, A Little Man, a Dumb Birdie, a Cage and the World; short stories); Maniuś Bany (1980, Maniuś Bany; short stories); Krzywe drogi (1987, Crooked Roads; including the story Stary doktor [The Old Doctor] about Janusz Korczak]; short stories); Judaizm jako los (1993, Judaism as Fate; essay); Tamta strona (1997, The Other Side; novel, published posthumously). 


\section{Content and Interpretation}

Bogdan Wojdowski's extensive, ground-breaking epic embraces the period of the existence of the Warsaw Jewish ghetto from its establishment in 1940 through the socalled Grosse Aktion in September 1942, when most of its inhabitants were sent to the gas chambers in Treblinka. Within its elaborate and artistic composition, the book provides a comprehensive and reliable account of these tragic historical events. The title can be understood in a realistic and symbolic way. It refers to the great famine, and to an actual event, when German soldiers shot a Polish tram driver who was illegally delivering bread to the starving Jews inside the ghetto. The story depicts the gradual annihilation of the ghetto seen through the eyes of a boy with the allusive name David Fremde (alien), belonging to the same age group as Wojdowski. Without commentary, the boy relates his detailed observations with nightmarish scenes of misery, corruption, ugliness, and despair. The novel offers a complex panorama of the ghetto community along human, economic, professional, and social lines from the Jewish upper class to the poor craftsmen, thieves and prostitutes.

By leaving home to smuggle some food, David was serendipitously saved from deportation and extermination. His grandfather, the pious patriarch of his family, took David away from his parents and sent him to the Aryan side of the wall dividing Warsaw, instructing him: "Forget you are Jewish. [...]. Live a wild dog's life. Skirt away from people but go on living... Forget who you are. Forget who your father and mother are. Forget who your grandparents were. You must have a heart of stone." (Wojdowski, 1997, pp. 46-47) Autobiographical allusions determine the character and expression of the novel. Wojdowski preserved the memory of the exterminated Jews in his literary strategy, stating that "during the day you have to carry the weight of the dead who are dying now, and at night you have to carry the weight of the dead who died a long time ago" (Molisak, 2004, p. 162). Bread is a leading motif of the book, a symbol of surviving during cruel times of starvation. Wojdowski's "novel symbolically keeps all exterminated Jews alive, just as bread kept alive the ghetto inhabitants." (Gawliński, 2020, p. 1) The novel's action hardly ever crosses the ghetto walls thereby demonstrating the desperate isolation of its inhabitants. Most of Wojdowski's writing deals with the deadly insecurity of existence with walls separating in a physical as well as in a metaphorical sense. "The wall divided people and that's why it was erected; I cannot express it more briefly", since "each look may be the last one." (Polonsky, Adamczyk-Garbowska, 2001, xxi). The other side "throwing bread to the dead" would be in its symbolic importance an "eternally existing space of the ghetto outside of time, while the Holocaust continues" (Molisak, 2004, p. 162). Wojdowski's last work, the unfinished novel The Other Side, takes place after the war in a resort near Warsaw in a dilapidated holiday house similar to Paziński's $\rightarrow$ The Boarding House. 


\section{Main Topics and Problems}

Wojdowski's 500-page novel integrates different genres and modes of literary writing. It is partly autobiographic and at the same time a fictional record of the Holocaust. It has no delineated plot, it is rather a sequence of different, drastic in their brutality, shocking scenes, dialogues, and innumerable instances of human degradation caused by brutal repression, hunger and disease. It can be regarded as a vast biographical portrayal of people of different social backgrounds along with the main character, locked up in the ghetto. The author places "spiritual values in the principal character's psyche, in his dreams and fantastic associations, and his feverish lyricism." (Gawliński, 2020, p. 1) Wojdowski's mosaic of Jewish fates is filled with references to Jewish tradition, to the cultural, social but also linguistic Polish-Jewish heritage. That's why the novel is also presented as an "example of polyphonic narrative art, creating an authentic image of everyday life in the ghetto preserving in memory all those cultural contents which the occupiers wanted to destroy." (Höllwerth, 2019, pp. 5-7) The author took the opening sentence of his novel from the Bible, reminiscent of his father's prayers in the once happy days before their captivity in the ghetto, which also often led to despairing situations, and blasphemous arguments with God. "Jakow, Jakow, where are you?... I am here. I am dying, therefore I am. [...] The logic of faith is hopeless when faced with the reality of the Shoah, [...] drawing any analogy between Gomorrha and the ghetto is groundless. Also interpreting the present Jewish tragedy in terms of religious guilt and punishment is futile”. (Gawliński, 2020, p. 1) Bread for the Departed can be regarded as a biographical documentary and a poetic requiem for the victims of the Warsaw Ghetto at the same time. Wojdowski's later narratives touch the same questions of the Jewish tragedy revealing the author's predilection for parabolic compositions. A characteristic feature of Wojdowski's book is the usage of different languages spoken by its varied characters stretching from Polish, Yiddish and Hebrew to German and slang of children and criminals. That is why Bread for the Departed may also function as an aural representation not only of the ghetto but also of the once-thriving Jewish Warsaw. As a writer Wojdowski seems the most closely related to the autobiographical book The Empty Water (1964) by Krystyna Żywulska. Like Julian Tuwim in 1944 ( $\rightarrow$ We, Polish Jews), Wojdowski perceptively described the existential situation of Polish Jews almost half-century later in an excellent essay Judaism as Fate published in 1993.

\section{Cited Works}

Gawliński, S. (2002). Bread for the Departed (Chleb rzucony umarłym) In: T. Riggs, ed., Reference Guide to Holocaust Literature. Available at: https://www.encyclopedia.com/arts/encyclopedias-almanacs-transcripts-and-maps/bread-departed-chleb -rzucony-umarlym [Accessed: 22.07.2019]. Höllwerth, A. (2019). „Kontaminierte Landschaften“. Mitteleuropa inmitten von Krieg und Totalitarismus. Eine exemplarische Bestandsaufnahme anhand von literarischen Texten. Berlin et al: Peter Lang. Molisak, A. (2004). Judaizm jako los. Rzecz o Bogdanie Wojdowskim. Warszawa: Wydawnictwo 
„Cyklady“. Polonsky, A., Adamczyk-Garbowska, M. (2001). Contemporary Jewish Writing in Poland. Lincoln: University of Nebraska Press. Wojdowski, B. (1997). Bread for the Departed. Evanston: Northwestern University Press.

\section{Further References}

Bieńkowski, Z. (1976). Zamach na epikę. Twórczość, 28(2), pp. 3-5. Grynberg, H., Levine, Madeline, G. (1997). Bogdan Wojdowski, My Brother. New England Review, 18 (4), pp. 8-10. Grynberg, H. (1998). Umarli i chleb. Midrasz, 2(4), pp. 16-17. Łukasiewicz, J. (1972). Chleb rzucony umarłym. Tygodnik Powszechny, (no 28). Molisak, A. (2002). Modlitwy kapłanów, modlitwy żebraków. Teksty Drugie, 13(1-2), pp. 197-208. Smola, K. (2011). Mimikry und jüdische Identität(en) in der zeitgenössischen polnischund russisch-jüdischen Literatur. Zeitschrift für Slawistik, 56(4), pp. 468-484. Zawada, A. (1994). Każde spojrzenie może być ostatnim. Odra, 34(11). 